\title{
Index
}

Academic literature, 1

Academic streaming, 55

Academy of Singapore Teachers

$$
\text { (AST), 74-75 }
$$

Advanced Level subjects, 67-68

All Party Commission and report on

Chinese education, 32-34

All-Party Report on Chinese

Education, 41-42

Allied educators, 72

Anglophile, 18

Anglophone, 18

model of formal teacher training, 19

Asian Values debate, 4-6

Autonomous schools, 56-57

Bilingual education, 46

Bilingualism, 47, 53

British colonial era, 29

British East India Company (EIC), 13

Centre for Research in Child

Development (CRCD), 76-77

Centre for Research in Pedagogy and Practice (CRPP), 76-77

Character and Citizenship Education (CCE), 70

Childhood education, 81

Chinese, 19-20

Chinese-language schools, 23

language, 64-65

Chinese education, 23-24, 30

All Party Commission and report on, 32-34

Choice, 57, 67

City-state, 9

Colonial institutions, 13

Colonial schooling in America, 15
Colonial state, 1-2, 79

Commonality, 53

Communication, 9

Communism, 29

Competencies, 70

Competition, 57

Confucian ethics, 5

Content knowledge, 19

Convent of Holy Infant Jesus (CHIJ), 14

Creative thinking skills, 69

Crisis legitimation, 3

Curricula, students and, 53-56

Curricular innovation, 61

Curriculum framework, 50

Cyberbullying, 67

Decolonisation, 29

Developmental state and education, 2-4

Differentiation of school system, 67-69

Diploma in Education Administration, 61

Direct Entry Scheme to Polytechnic Programme, 68-69

Diversity, 57, 67

Domestic policy of city-state, 9

Early educational institutions

(1819-1919), 13-17

Mission Schools, 13-15

Secular Schools, 15-17

Education Bill, 36

Education Endowment Scheme, 58

Education policy, 10

in Colony of Singapore, 79-80

under new PAP administration, 36-38 
Education system, 4, 10 in modern Singapore, 19

Education(al). See also Teacher education, 11-12, 26, 29, 37

activities, 11-12

degree programme, 63

developmental state and, 2-4

educational-economic integration, 3

history in Singapore, 11-13

infrastructure, 4

marketisation of, $57-58$

pathways, 68-69

policy shifts and impact of Chinese nationalism, 17-18

post-war state formation and, 29-32

in Singapore, 9

survivalist discourse and, 44-48

wastage, 53-54

White Paper and education ordinance, 34-36

Educational Research Association of Singapore, 60

Edusave scheme, 58-59

English, 79-80

English-medium schools, 22

Equal educational opportunity for all, 26

Equality, 5

Explicit teaching of critical thinking skills, 69

Extended bilingual, 54-55

Flexibility, 67

Formal education system, 19

Formal teacher education up to $1950,25-27$ training, 1-2

Free primary education, 26

Fujian province, 20

General Certificate of Education Ordinary Level examinations, 67-68

Gifted Education Programme, 55
Globalisation, meeting challenges of, 69-70

Goh Doctrine, 10

Goh Report, 71

Government educational policy, 22

Higher National Institute of Technical Education Certificate, 68-69

Ideal product, 47

Independent schools, 56-57

Indians, 19-20

Indigenous leadership, 22

Indigenous population, 20

Inequity, 20

Informal approach, 1-2

Information and Communications

Technologies (ICTs), 69

Innovation-driven growth, 67

Institute of Education (IE), 41

and College of Physical Education, 80

Institute of Technical Education Skills Certificates, 68

Integrated national education system, 29

Integrated programmes, 67-68

International Association for Evaluation of Educational Achievement, 1

International rankings, 1

Junior College/Upper Secondary

Education Review

Committee, 67

Kynnersley Report (1902), 17, 19

Labour Front government, 32, 38-39, 41-42

Laissez-faire policy, 71-72

Language, 20, 54 competence, 55

Language Elective Programme, 55

Lingua franca, 30 
Malay education, 20-23

Malayanisation, 33-34

Marketisation of education, 57-58

Masterplan, 69

for Information Technology in Education, 69

Ministry of Education, 64, 67-68, 77

Mission Schools, 13-15

Monolingual, 54-55

Multilingual equality shift, 79-80

Multiple Pathways to Success, 68

Multiracialism, 42-44

Music Elective Programme, 55

Nanyang Technological University (NTU), 62, 75, 80-81

National Education (NE), 53, 70

National Institute of Education (NIE). See also Institute of Education (IE), 1, 8, 63, 75, 80-81

further differentiation of school system, 67-69

further policies to deal with social equity issues, 70-72

meeting challenges of globalisation, 69-70

teacher education at, 72-78

Nationalism, 29

Normal bilingual, 54-55

One-size fits all instructional methods, 69

Online sexual grooming captured public attention, 67

Organisation for Economic Cooperation and Development (OECD), 1

\section{Parentocracy, 71}

People's Action Party (PAP), 31, 35, 53 education policy under new PAP administration, 36-38

Performance legitimacy, 3

Policies-Practice-Preparation model,
Polytechnic Foundation Programme, 68-69

Pondok, 22

Post-colonial state, 1-2, 79

Post-war state formation and education, 29-32

Postgraduate Diploma in Education (PGDE), 63-64

Practice of Educational Principles, $59-60$

Practicum curriculum, 59-60

Pre-service teacher education, 81-82

Primary schooling, 54-55

Principles of Education Practice, $50,59-60$

Professional Development Continuum Model, 74

Professional learning communities (PLCs), 74-75

Professional teacher, 19

Programme for International Student Assessment (PISA), 1

Public education, 82

Qualifications in English, 19-20

Raffles College, 79

Raffles Institution, 15-16

School Excellence Model, 57-58

School system, differentiation of, $67-69$

School-based skills, 19

Science and technology education, 45-46

Science of Learning in Education Centre (SoLEC), 76-77

Second World War, 29

Secular Schools, 15-17

Self-cultivation, 5

Self-governance, 29

to independence, 38-39

Self-reliance, 5

Shadow education, 82 
Singapore, 1, 9, 46, 79

$10-$ Year Plan for education in, 30

Chinese education, 23-24

different populations, different histories, 20-25

early educational institutions, 13-17

education system, 19, 53, 69

educational history, 11-13

educational policy shifts and impact

of Chinese nationalism,

$17-18$

formal teacher education up to 1950, 25-27

implications on teacher training, 48-50

Malay education, 20-23

multiracialism, 42-44

reflections on future of teacher education in, 80-82

self-governance to independence, 38-39

survivalist discourse and education, 44-48

Tamil education, 24-25

teacher education, 1

unexpected independence of, 42

unique geographical and historical context, 10-11

Singapore Bus Workers' Union

(SBWU), 32

Singapore English Teachers' Union, 34

Singapore Free School, formal education, 20-21

Singapore Open Data Licence version 1. $0,65,73$

Singapore Teaching Practice (STP), 75

Social emotional competencies, 70

Social equity, 58-59

further policies to deal with social equity issues, $70-72$

Social Service Institute, 81

Special educational needs, 72

Straits Chinese Magazine, The, 16

Streaming, advent of, 53-56
Student Learning Space, 69

Student well-being, 67

Students and curricula, 53-56

Tamil education, 24-25

Tamil Language, 64-65

Teach Less, Learn More initiative, 69

Teacher education, 2, 67, 79

development, 29

at National Institute of Education, 72-78

reflections on future of teacher education in Singapore, 80-82

reforms in teacher education in 1980s and 1990s, 59-66

in Singapore, 82

Teacher Education Conference

Continuation Committee (TECCC), 49

Teacher preparation, 79

in Singapore, 1

Teachers

implications on teacher training, $48-50$

professional development, 74 role, 70

Teachers' Training College (TTC), 27, 41, 79-80

Technical education, 45

Thinking Schools, Learning Nation

(TSLN), 67, 69

Traditional Chinese-medium schools, 23

Trends in International Mathematics and Science Study (TIMSS), 1

Universitisation, 76

differentiation of students and curricula, 53, 56-57

marketisation of education, $57-58$

reforms in teacher education in

1980s and 1990s, 59-66

social equity, 58-59 
University of Cambridge Local

Examination Syndicate (UCLES), 27

Uplifting pupils in life and inspiring families taskforce

(UPLIFT), 72
Vernacular language, 20

White Paper and education ordinance, 34-36

White Paper on Education Policy, 34

Woolley Report, 17 